\title{
АНЕСТЕЗІОЛОГІЧНИЙ МЕНЕДЖМЕНТ ЕМБОЛІЗАЦІї МАТКОВИХ АРТЕРІЙ - ДОСВІД ПЕРШИХ ТРЬОХ КЛІНІЧНИХ ВИПАДКІВ
}

\author{
М.В. Кунатовський, С.О. Тарасенко, О.О. Єфімова \\ Украӥнський науково-практичний центр ендокринної хірургії, трансплантації \\ ендокринних органів і тканин МОЗ України
}

Актуальність. Згідно світових досліджень, міома матки зустрічається у 20\% жінок старше 30 років і більш ніж у $40 \%$ жінок старше 40 років. Альтернативою хірургічному лікуванню в наш час стало використання рентген-хірургічного лікування міом матки - емболізації маткових артерій (ЕMA) - мінімально інвазивного і органозберігаючого методу [1]. Найбільш поширеним явищем у ранньому післяопераційному періоді $\epsilon$ розвиток так званого післяемболізаційного синдрому. Він має такі прояви як короткотривала гіпертермія, кров'янисті виділення, нудота. Однак одним із найбільш неприємних проявів цього синдрому $\epsilon$ інтенсивний післяопераційний біль [2].

Мета: Оцінка ефективності традиційних методів знеболювання та збалансованої (мультимодальної) аналгезії [3] (ЗММА) (епідуральна анестезія/ аналгезія) при ЕMA.

Матеріали та методи. У відділенні інтервенційної радіології Науково-практичного центру ендокринної хірургії, трансплантації ендокринних органів та тканин MO3 України у лютому-квітні 2018 року було виконано перші три планові ЕМА пацієнткам 3 діагнозом «симптоматична лейоміома

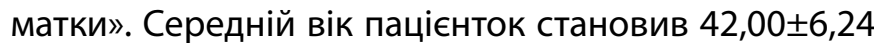

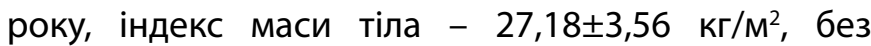
супутньої патології, ризик анестезії 1 бал за ASA.

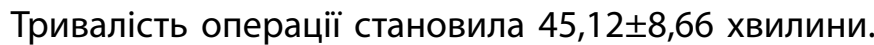
Комплекс ЗММА включав у себе премедикацію за 25-30 хвилин за принципом pre-emptive analgesia: внутрішньовенне введення дексаметазону 4-8 мг, НПЗП з ліпофільними властивостями декскетопрофену 50 мг та метоклопраміду 20 мг. Також виконували катетеризацію епідурального простору на рівні L2-L3 та вводили 25 мг розчин бупівакаїну. Цей комплекс ЗММА був застосований у 2 пацієнток, а одній пацієнтці 3 лейоміомою матки виконувалась ЕМА за традиційною в клініці методикою анестезіологічного забезпечення. Традиційна методика включала премедикацію шляхом внутрішньом'язового введення морфіну 10 мг, внутрішньовенного введення декскетопрофену 50мг,дексаметазону 4-8мг за 30-40хвилиндопочатку операції. 3 антиеметичною метою призначався на початку операції метоклопрамід внутрішньовенно в дозуванні 10 мг. В післяопераційному періоді у пацієнток, які отримали ЗММА, використовувалось знеболення за принципом preventive analgesia: внутрішньовенно вводилися декскетопрофен кожні 8 годин протягом 2 діб, парацетамол або метамізол натрію в дозуванні 1000 мг кожні 12 годин, а також проводилася інфузія 0,125\% розчину бупівакаїну зі швидкістю 4 мл/год (5 мг/год). У пацієнтки, яка отримувала традиційну методику, застосовувалися одразу після операції фентаніл шляхом внутрішньовенної інфузії зі швидкістю 0,2 мг/год, декскетопрофен або метамізол натрію через 4-6 годин після операції, а також внутрішньом'язово вводився 1,0 мл омнопону 3Н 1\% кожні 12 годин.

Виконувалась оцінка аналгетичного компоненту анестезії та рівня післяопераційного болю за візуальною аналоговою шкалою (ВАШ). Частота виникнення післяопераційної нудоти і блювання (ПОНБ) оцінювалась за шкалою, де $0=$ відсутні нудота i/або блювання, 1 = нудота, 2 = позиви до блювання, 3 = блювання). Важка ПОНБ оцінювалась як сумарна частота показників 2 и 3.

Результати. Аналізуючи дані, було відмічено, що загальне споживання фентанілу за операцію було нижчим у пацієнтів, у яких використовувалась 3ММА, ніж у пацієнтки, яку вели за традиційною методикою. Так, упацієнтів з ММАвдалосяповністювідмовитися від застосування наркотичних анальгетиків в післяопераційному періоді, тоді як за традиційною методикою вони були застосовані для знеболення протягом першої доби у вигляді внутрішньом'язової ін'єкції Омнопону та внутрішньовенної інфузії фентанілу. Також було відмічено, що рівень болю за ВАШ через 3 години після закінчення операції був нижчим у пацієнток, у яких застосовувалась ЗММА, і становив 0-2 бали, ніж у пацієнтки, яку вели за традиційною методикою (7-8 балів). Також відмічено 
виникнення важкої ПОНБ у пацієнтки, в якої використовувалася традиційна методика анестезії. Частота ПОНБ у пацієнтів з ЗММА становила 0\%. Ми вважаємо, що зниження частоти ПОНБ в пацієнтів 3 ЗММА зумовлено достовірно нижчим рівнем болю, який є одним із тригерів нудоти та блювання, інтраопераційним зменшенням застосування опіоїдів та повною відмовою від їх використання в післяопераційному періоді.

\section{Висновки}

1. Збалансована (мультимодальна) аналгезія (епідуральна анестезія/аналгезія) при EMA $\epsilon$ доцільною за рахунок адекватного рівня аналгезії.

2. У пацієнтів з використанням ЗММА показник болю за ВАШ був набагато нижчим, ніж при використанні традиційної методики анестезії.

3. ЗММА дала змогу відмовитися в післяопераційному періоді від наркотичних анальгетиків, а також характеризувалася відсутністю ПОНБ.
Ключові слова: емболізація маткових артерій, мультимодальна аналгезія, епідуральна аналгезія.

\section{ЛІТЕРАТУРА}

1. КалиновскаяО.И. Эмболизация маточныхартерий как метод сохранения фертильной функции женщины / О.И. Калиновская // Медичні аспекти здоров'я жінки. - 2011. - № 8(49). - С. 51-55.

2. Прогностические признаки выраженности болевого синдрома после эмболизации маточных артерий у женщин с лейомиомой матки / С.А. Сосин, В.В. Приворотский, И.Е. Зазерская, В.Н. Кустаров // Гинекология. -2017. - № 19 (5). C. 30-33. DOI: 10.26442/2079-5696_19.5.30-33

3. Bilhim T, Pisco JM. The Role of Nonsteroidal AntiInflammatory Drugs (NSAIDs) in the Management of the Post-Embolization Symptoms after Uterine Artery Embolization. Pharmaceuticals (Basel, Switzerland). 2010; 3(6):1729-1738. doi:10.3390/ ph3061729

Дата надходження до редакції 24.10.2018 p.

https://doi.org/10.24026/1818-1384.4(64).2018.150183

\title{
МІНІНВАЗИВНІ МЕТОДИ ЛІКУВАННЯ МЕТАСТАТИЧНОЇ ХВОРОБИ ВИСОКОДИФЕРЕНЦЙОВАНОГО РАКУ ЩИТОПОДІБНОЇ ЗАЛОЗИ
}

\author{
П.О. Ліщинський, Ю.Е. Чирков \\ Украйнський науково-практичний центр ендокринної хірургї, трансплантаиії \\ ендокринних органів і тканин МОЗ України
}

Вступ. Папілярний рак щитоподібної залози становить близько 80\% всіх видів раку щитоподібної залози. 10-річна виживаність становить 93\%, незалежно від стадії процесу. Тотальна тиреоїдектомія 3 центральною дисекцією шиї, лімфаденектомією - найбільш виправданий обсяг оперативного лікування. Актуальність роботи зумовлена необхідністю редукції росту метастазів 3 мінімальним ризиком ускладнень. Мініінвазивні методи лікування метастатичного процесу папілярного раку щитоподібної залози після комбінованого лікування - недорогий та відносно безпечний спосіб лікування у порівнянні 3 повторним оперативним втручанням.

Мета: оцінити ефективність та безпечність етанолової склеротерапії метастазів високодиференційованого раку щитоподібної залози у разі пролонгації злоякісного процесу.

Матеріали і методи. У дослідженні брали участь 16 хворих, з них 4 чоловіки, 13 жінок. Середній вік хворих - 43 роки (від 17 до 66 років). Хворим проведено етанолову деструкцію метастатичних лімфовузлів шиї шляхом перкутанного введення препарату під контролемУЗД. 96\% етанол спричиняє дегідратацію та некроз клітин метастазу в результаті тромбозу дрібних судин, що призводить до ішемії та деструкції пухлини. Хворим проводився моніторинг рівня тиреоглобуліну, антитіл до тиреоглобуліну крові через 3, 6 та 12 міс, УЗД органів шиї в динаміці (наявність кровотоку, ехогенність, ріст метастатичного лімфовузла).

Результати та обговорення. На основі проведеного проспективного аналізу, метод етанолової абляції у 13 хворих дав позитивний 